УДК 343.342

DOI https://doi.org/10.51989/NUL.2021.5.18

\title{
ДО ПРОБЛЕМИ АНТИКОРУПЦІЙНОЇ БЕЗПЕКИ ЯК ОБ'ЄКТА КОРУПЦІЙНИХ КРИМІНАЛЬНИХ ПРАВОПОРУШЕНЬ І АДМІНІСТРАТИВНИХ ПРАВОПОРУШЕНЬ, ПОВ'ЯЗАНИХ ІЗ КОРУПЦІЄЮ
}

\author{
Дем'як Павло Юрійович, \\ аспірант третього року навчання \\ Волинського національного університету імені Лесі Українки
}

у статті антикорупційна безпека України розуміється як частина національної безпеки нашої держави, що вимагає належного визначення ії викликів, загроз та небезпек, що зумовлює вироблення належних заходів протидії відповідним негативним явищам. Запропоновано виокремлювати антипорядок, пов'язаний із корупцією, який полягає в порушенні особами, уповноваженими на виконання функцій держави або місцевого самоврядування, прирівняними до них особами, претендентами на відповідні посади, а також особами, які припинили чи припиняють вказану діяльність, антикорупційних вимог, заборон та обмежень, передбачених Законом України «Про запобігання корупції». Корупцію й антипорядок, пов'язаний із корупцією, визнано суспільними ризиками, які деструктивно впливають на антикорупційну, а отже, на національну безпеку України, характеризуються різною інтенсивність такого впливу. Корупція є загрозою, антипорядок - викликом для антикорупційної та національної безпеки України. Спільність об'єкта, на який посягають корупційні кримінальні правопорушення й адміністративні правопорушення, пов'язані з корупцією, вказує на те, що відповідні види правопорушень є досить близькими за об'єктивними та суб'єктивними ознаками, що дає підстави розглядати їх як єдине ціле, частинами якого є негативні явища, що посягають на антикорупційну безпеку як частину національної безпеки України.

Ключові слова: корупція, антипорядок, пов'язаний із корупцією, національна безпека, антикорупційна безпека, антикорупційні вимоги, антикорупційні заборони, антикорупційні обмеження.

\section{Demyak Pavlo. To the problem of anti-corruption security as an object of corruption criminal offenses and administrative offenses related to corruption}

The article understands the anti-corruption security of Ukraine as part of the national security of our state, which requires proper identification of its challenges, threats, and dangers, which in turn leads to the development of appropriate measures to combat the relevant negative phenomena. It is proposed to single out the anti-order related to corruption, which consists in the violation of anti-corruption requirements, prohibitions by persons authorized to perform the functions of the state or local self-government, persons equated to them, candidates for relevant positions, as well as persons who have stopped or are terminating these activities. and restrictions provided by the Law of Ukraine "On Prevention of Corruption". Corruption and anti-corruption-related order are recognized as public risks that have a destructive effect on the anti-corruption and, consequently, national security of Ukraine and are characterized by varying intensities of such influence. Thus, corruption is a threat, and anti-order is a challenge to Ukraine's anti-corruption and national security. The commonality of the object encroached upon by corruption and administrative offenses related to corruption indicates that the respective types of offenses are quite close in objective and subjective terms, which gives grounds to consider them, parts of which are negative phenomena that encroach on anti-corruption security as part of Ukraine's national security.

Key words: corruption, anti-corruption-related anti-order, national security, anti-corruption security, anti-corruption requirements, anti-corruption prohibitions, anti-corruption restrictions.

З ухваленням антикорупційного законодавства України, зокрема Закону України «Про запобігання корупції» від 14 жовтня 2014 р. № 1700-VII, а також відповідних змін до Кримінального кодексу України (далі - КК) та Кодексу України про адміністративні правопорушення (далі - КУпАП) змінилася парадигма охорони порядку 
суспільних відносин у сфері гарантування антикорупційної безпеки. Зазначеними законодавчими актами було закріплено поділ правопорушень на корупційні та ті, що пов'язані з корупцією [1]. Попри відмінності між вказаними видами правопорушень, вони мають декілька спільних ознак, серед яких порушення антикорупційної безпеки, що дає змогу розглядати корупційні кримінальні правопорушення й адміністративні правопорушення, пов'язані з корупцією, як єдине ціле.

Поняття «антикорупційна безпека» у законодавстві України не використовується. Насамперед приділимо увагу тому, що треба розуміти під вказаним поняттям.

Поняття «безпека» $\epsilon$ основним словом у вказаному термінологічному звороті (3 лат. securitas - «без турботи, страху», із

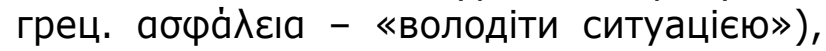
поєднує свободу чи захист від небезпеки або тривоги, а також заходи, ужиті для гарантування безпеки країни, особи, цінності [2, с. 1062].

У науковій юридичній літературі поняття «безпека» розглядається в широкому значенні як стан «наявності сприятливих умов для функціонування складної системи, за яких вплив зовнішніх і внутрішніх чинників не приводить до її дестабілізації» [3]. Такими чинниками, на наш погляд, $є$ соціальні ризики, які відрізняються за ступенем дестабілізаційного впливу [4] та набувають форм викликів, загроз і небезпек. Виклики $\epsilon$ найбільш поширеними, імовірними причинами, повсякденними імпульсами локальних дестабілізацій, що ситуативно коригують, проте не змінюють якість суспільних відносин у їхньому фрагментарному вираженні. Загроза характеризується більшим деструктивним впливом порівняно з викликом, оскільки ї̈ виникнення означає суттєве підвищення ймовірності послаблюючого або руйнівного впливу зовнішньої або внутрішньої сили на об'єкт. Загрози доречно сприймати як причину ймовірних якісних змін значного масштабу, які впливають на суспільний порядок, проте не ставлять під сумнів життєздатність суспільної системи як такої. Небезпеки $є$ крайньою формою деструктивного впливу, критичним проявом дестабілізації, оскільки спроможні стати причиною знищення певного сус- пільного фрагмента, суспільства загалом, а в умовах глобалізації - знищення світу людини загалом [5].

Згідно із Законом України «Про основи національної безпеки України» від 19 червня 2003 р. № 964-IV, який втратив чинність 8 липня 2018 р. [6], національна безпека визначалася як захищеність життєво важливих інтересів людини і громадянина, суспільства і держави, за якої забезпечуються своєчасне виявлення, запобігання і нейтралізація реальних та потенційних загроз національним інтересам, зокрема у сфері боротьби 3 корупцією (ст. 1), а однією із загроз національним інтересам і національній безпеці України у сфері державної безпеки було визнано загрози поширення корупції в органах державної влади, зрощення бізнесу і політики, організованої злочинної діяльності (ст. 7). Водночас у чинному Законі України «Про національну безпеку України» від 21 червня 2018 р. № 2469VIII про це не йдеться [7].

У Стратегії національної безпеки України, затвердженої Указом Президента України від 26 травня 2015 р. № 287/2015, яка натепер уже втратила чинність, корупція також визначалася однією з актуальних загроз національній безпеці України (п. 3.3) [8]. Водночас у чинній Стратегії національної безпеки України, що затверджена Указом Президента України від 14 вересня 2020 р. № 392/2020, про це прямо не йдеться, однак зазначається, що реалізація пріоритетів національних інтересів України та гарантування національної безпеки забезпечуватимуться, зокрема, за таким напрямом, як захист особи, суспільства та держави від правопорушень, зокрема корупційних, а поточними та прогнозованими загрозами національній безпеці та національним інтересам України визначено корупцію, яка перешкоджає виведенню української економіки з депресивного стану, унеможливлює ії стале і динамічне зростання, підвищує вразливість до загроз, підживлює кримінальне середовище [9].

У науковій літературі також поширена думка, відповідно до якої корупція визнається загрозою національній безпеці. Наприклад, О.М. Костенко характеризує корупцію крізь призму соціального нату- 
ралізму та виокремлює корупцію кризового типу, відзначає, що вона $\epsilon$ загрозою національній безпеці України, оскільки корупція «українського зразка», що породжена кризою сучасного українського суспільства, «здатна поглиблювати кризу суспільства, маючи властивість зводити нанівець будь-які політичні, економічні, правові, моральні реформи» [10, с. 49-50]. У листопаді 2019 р. було проведено Міжнародну науково-практичну конференцію «Корупція як загроза національній безпеці України: попереджаємо, протидіємо, переслідуємо» [11, с. 577]. Окремі науковці у своїх наукових пошуках ідуть ще далі й обґрунтовують наукову позицію, згідно з якою родовим об'єктом корупційного підкупу має визнаватися таке правове благо, як національна безпека України, а також доводять спрямованість корупційного підкупу як кримінального правопорушення на завдання шкоди благам, що охоплюються поняттям «національна безпека України» $[12$, c. 95$]$.

Отже, саме корупція $€$ загрозою, а не викликом чи небезпекою для національної безпеки України. Корупція характеризується істотним, але не фатальним дестабілізуючим впливом на суспільство. M.I. Мельник влучно назвав корупцію корозією влади [21]. Корупція як загроза може завдати руйнівного впливу на національну безпеку України, а ії існування вимагає якісного оновлення вектора правової політики, що має бути спрямована на нейтралізацію дії такої загрози.

Водночас, як зазначалося вище, окрім корупційних порушень, Закон України «Про запобігання корупції» виокремлює ще й дотичні до них правопорушення, пов'язані з корупцією. На відміну від перших, вони сутнісно характеризуються тим, що не мають ознак корупції, але порушують встановлені цим Законом вимоги, заборони й обмеження [1]. За окремі з них встановлена адміністративна відповідальність у гл. 13-А КУпАП.

Чи можна стверджувати, що адміністративні правопорушення, пов'язані з корупцією, також $\epsilon$ соціальним ризиком для національної безпеки України?

Як зазначалося вище, правопорушення, пов'язані з корупцією, порушують антикорупційні вимоги, заборони й обме- ження. 3 огляду на те, що їх перелік чітко в Законі України «Про запобігання корупції» не виписаний, зазвичай науковці не розмежовують одне з одним антикорупційні вимоги, заборони й обмеження [28, с. $78-110,115-116 ; 47$, с. 36, 38-61, 73]. Проте аналіз Закону України «Про запобігання корупції» усе ж дає підстави стверджувати протилежне: антикорупційні вимоги, заборони й обмеження $\epsilon$ різними запобіжниками на публічній службі. Як обґрунтовано стверджує 3.А. ЗагинейЗаболотенко, антикорупційні вимоги - це передбачені в Законі України «Про запобігання корупції» норми, правила, яким повинні підлягати особи, на яких поширюється цей Закон, антикорупційні заборони - правила, що не дозволяють особам, на яких поширюється дія цього Закону, здійснювати певні дії під час виконання покладених на них обов'язків, антикорупційні обмеження - обмежувальні умови щодо антикорупційного поведінки осіб, на яких поширюється дія цього Закону [49, с. 107].

Залежно від того, на яку категорію суб'єктів вони поширюються, у вказаному Законі передбачається «набір» таких вимог, заборон і обмежень для претендентів на посади, на діючих осіб, уповноважених на виконання функцій держави або місцевого самоврядування, а також на осіб, які припинили здійснення цих функцій. Вочевидь, найбільший перелік антикорупційних вимог, заборон і обмежень передбачено саме для осіб, які виконують функції держави або місцевого самоврядування. Наприклад, такі особи повинні дотримуватися таких вимог: уживати заходів щодо врегулювання реального або потенційного конфлікту інтересів; подавати декларацію особи, уповноваженої на виконання функцій держави або місцевого самоврядування; повідомляти про відкриття суб'єктом декларування або членом його сім'ї валютного рахунку в установі банку-нерезидента та про суттєві зміни в майновому стані суб'єкта декларування; не розголошувати і не використовувати іншим способом конфіденційну та іншу інформацію з обмеженим доступом, яка стала відома у зв'язку з виконанням своїх службових повноважень і професійних обов'язків, окрім випадків, установлених законом [1]. 
Отже, як убачається з аналізу Закону України «Про запобігання корупції», коло антикорупційних вимог, заборон та обмежень настільки широке, що охоплює всю професійну та службову діяльність осіб, уповноважених на виконання функцій держави або місцевого самоврядування, що забезпечують законність публічної служби, гарантують ї̈ здійснення виключно для досягнення публічних, а не приватних інтересів. Тому й порушення закріплених у законодавстві антикорупційних вимог, заборон і обмежень здатне спричинити ту ж саму корозію влади, про яку писав М.I. Мельник [13]. Окрім того, деякі антикорупційні вимоги, як зазначалося вище, поширюються й на осіб, які лише претендують на зайняття певних посад публічної служби, а деякі антикорупційні вимоги, заборони й обмеження також мають переживаючу дію, тобто поширюються на осіб, які припинили виконання відповідних повноважень. Окремі вимоги - на все життя (наприклад, ідеться про заборону не розголошувати або використовувати іншим способом у своїх інтересах інформацію, яка стала їм відома у зв'язку з виконанням службових повноважень, окрім випадків, установлених законом) [1].

На міжнародному рівні також стандарт антикорупційної поведінки публічних службовців визначається в антикорупційних конвенціях. Наприклад, антикорупційні обмеження в діяльності публічних службовців закріплено в Конвенції ООН проти корупції. До них віднесено такі: 1) подання державних декларацій про позаслужбову діяльність, заняття, інвестиції, активи та про суттєві дарунки або прибутки, у зв'язку з якими може виникнути конфлікт інтересів стосовно їхніх функцій як державних посадових осіб (4. 5 ст. 8); 2) запобігання виникненню конфлікту інтересів і обмеження професійної діяльності колишніх державних посадових осіб у приватному секторі після їхнього виходу у відставку або на пенсію, якщо така діяльність або робота безпосередньо пов'язана з функціями, що такі державні посадові особи виконували в період їхнього перебування на посаді або за виконанням яких вони здійснювали нагляд (п. «е», ч. 2. ст. 12); 3) установлення кримінальної відповідальності публічних службовців у разі порушення ними антикорупційних обмежень [14]. Закріплення в міжнародних документах указаних обмежень разом із заходами, спрямованими на протидію корупції, свідчить про те, що відповідні порушення визнаються міжнародною спільнотою якщо не як однопорядкові, то близькі за змістом та ступенем впливу на правопорядок з охорони національної безпеки України від викликів та загроз.

Установлені в законодавстві антикорупційні вимоги, заборони й обмеження охоплюють максимально широке коло суб'єктів, що $\epsilon$ своєрідними законодавчими запобіжниками протиправної корупційної поведінки на публічній службі та під час здійснення інших видів діяльності, які підлягають «антикорупційному контролю» відповідно до Закону України «Про запобігання корупції», а також гарантом дотримання принципу законності під час здійснення професійної та службової діяльності вказаними особами, що забезпечує авторитет як органу чи установи, де така особа працює, так і держави та місцевого самоврядування загалом. Зазначені суспільні відносини $\epsilon$ впорядкованими та врегульованими нормами права, що визначають правовий статус осіб, які повинні їх дотримуватися у своїй діяльності, способи, порядок та методи регулювання, що робить можливим утілення правових норм антикорупційного законодавства в життя. Вказані суспільні відносини характеризуються ознаками правопорядку, що виокремлюються й аналізуються в науковій літературі з теорії права $[15$, с. $725-730$; 16 , с. $217-218 ; 17$. с. 104 ].

На наш погляд, родовим об'єктом правопорушень, пов'язаних із корупцією, $\epsilon$ правопорядок із дотримання особами, уповноваженими на виконання функцій держави або місцевого самоврядування, або прирівняними до них особами, або особами, які претендують на зайняття відповідних посад чи припинили таку діяльність, антикорупційних вимог, заборон і обмежень, передбачених Законом України «Про запобігання корупції».

Тому й адміністративні правопорушення, пов'язані з корупцією, які посягають на вказаний правопорядок, фактично $\epsilon$ соціальним ризиком для антикоруп- 
ційної, а отже, для національної безпеки України.

Саме ж негативне явище, яке полягає в недотриманні суб'єктами встановлених для них антикорупційних вимог, заборон і обмежень, будемо іменувати таким термінологічним зворотом, як «антипорядок, пов'язаний із корупцією», який має місце у зв'язку з тим, що особи, які зобов'язані дотримуватися антикорупційних вимог, заборон і обмежень, закріплених у Законі України «Про запобігання корупції». Порядок, як зауважує В.О. Туляков, перетворюється на антипорядок, право гібридизується: принцип доцільності поглинає законність та невідворотність відповідальності [18, с. 24].

Антипорядок, пов'язаний із корупцією, разом із власне корупцією, як вказувалося вище, $\epsilon$ соціальним ризиком для антикорупційної безпеки України. Таке твердження має право на існування та підкріплюється, зокрема, тим, що в Україні, як зазначав О.М. Костенко, існує корупція кризового типу. Такий тип корупції передбачає переосмислення підходів стосовно розуміння самої суті корупції й антипорядку, пов'язаного з корупцією, у контексті соціальних ризиків для антикорупційної безпеки України доцільно розглядати як єдине ціле. Проте, на відміну від корупції, антипорядок, пов'язаний із корупцією, на наш погляд, належить не до загроз, а до викликів антикорупційній безпеці, оскільки характеризується меншим рівнем деструктивного впливу на антикорупційну безпеку порівняно з корупцією. Як уже зазначалося вище, виклики $\epsilon$ повсякденними імпульсами лише локальних дестабілізацій, що ситуативно коригують, проте не змінюють якість суспільних відносин у їхньому фрагментарному вираженні. Такими властивостями, на нашу думку, наділений антикорупційний порядок, пов'язаний із корупцією.

Про близькість корупції та протиправної діяльності, пов'язаної з корупцією, свідчить і семантика вжитого в законодавстві слова «пов'язаний». В українській мові слово «пов'язувати» означає, серед іншого, «встановлювати спільність, зв'язок, взаємну залежність між ким-, чимнебудь // поєднувати в ціле, об'єднувати разом чим-небудь спільним» [19]. Отже, законодавець визнає, що порушення антикорупційних вимог, заборон і обмежень, хоча і не $\epsilon$ корупцією, проте може спричинити шкоду тому самому порядку суспільних відносин, що і сама корупція.

Водночас уважаємо, що сукупно корупція й антипорядок, пов'язаний із корупцією, здатні максимально деструктивно вплинути на антикорупційну безпеку держави, а тому в сукупності їх варто відносити до такого соціального ризику, як небезпека антикорупційній безпеці.

На підставі викладеного доходимо таких основних висновків, що стосуються розуміння антикорупційної безпеки як об'єкта корупційних кримінальних правопорушень і адміністративних правопорушень, пов'язаних із корупцією:

1) антикорупційна безпека України $\epsilon$ частиною національної безпеки нашої держави, що вимагає належного визначення ії викликів, загроз і небезпек, що зумовлює вироблення належних заходів протидії відповідним негативним явищам;

2) запропоновано виокремлювати антипорядок, пов'язаний із корупцією, який полягає в порушенні особами, уповноваженими на виконання функцій держави або місцевого самоврядування, прирівняними до них особами, претендентами на відповідні посади, а також особами, які припинили чи припиняють вказану діяльність, антикорупційних вимог, заборон і обмежень, передбачених Законом України «Про запобігання корупції»;

3) визначено, що родовим об'єктом адміністративних правопорушень, пов'язаних із корупцією, $є$ правопорядок із дотримання особами, уповноваженими на виконання функцій держави або місцевого самоврядування, або прирівняними до них особами, або особами, які претендують на зайняття відповідних посад чи припинили таку діяльність, антикорупційних вимог, заборон і обмежень, передбачених Законом України «Про запобігання корупції»;

4) корупцію й антипорядок, пов'язаний із корупцією, визнано суспільними ризиками, які деструктивно впливають на антикорупційну, а отже, на національну безпеку України, характеризуються різною інтенсивність такого впливу. Корупція $\epsilon$ загрозою, а антипорядок - викликом для антикорупційної та національної безпеки 
України. Водночас разом вони перетворюються якісно на такий соціальний ризик, як небезпека для національної безпеки;

5) спільність об'єкта, на який посягають корупційні кримінальні правопорушення й адміністративні правопорушення, пов'язані з корупцією, вказує на те, що відповідні види правопорушень $\epsilon$ досить близькими за об'єктивними та суб'єктивними ознаками, що дає підстави розглядати їх як єдине ціле, частинами якого $€$ негативні явища, що посягають на антикорупційну безпеку як частину національної безпеки України.

\section{ЛITEPATУРA:}

1. Про запобігання корупції : Закон України від 14 жовтня 2014 р. № 1700-VII. URL: https://cutt.ly/5Qrl411 (дата звернення: 01.08.2021).

2. Oxford Advanced Learner's Dictionary. 1995. URL: https://cutt.ly/jQrl3Sb (дата звернення: 01.08.2021).

3. Шемшученко Ю.С. Безпека національна. Юридична енциклопедія : у 6-и т. / редкол. : Ю.С. Шемшученко (відп. ред.) та ін. Київ : Українська енциклопедія, 1998. Т. 1. 672 с. URL: https://cutt.ly/7QrlOWq (дата звернення: 01.08.2021).

4. Anthony Giddens' and Ulrich Beck's conceptions of risk. November 27, 2015. URL: https://cutt.ly/FQrlLfv (дата звернення: 01.08.2021).

5. Балан М.I. Суспільство ризику: дестабілізаційні можливості. Державне управління: удосконалення та розвиток. 2019. № 2. URL: https://cutt.ly/LQrlJuN (дата звернення: 01.08.2021).

6. Про основи національної безпеки України : Закон України від 19 червня 2003 р. № 964-IV. URL: https://cutt.ly/bQrIMbA (дата звернення: 01.08.2021).

7. Про національну безпеку України : Закон України від 21 червня 2018 р. № 2469-VIII. URL: https://cutt.ly/kQrlBIZ (дата звернення: 01.08.2021).

8. Стратегія національної безпеки України, затв. Указом Президента України від 26 травня 2015 р. № 287/2015. URL: https://cutt.ly/KmJDE0q (дата звернення: 01.08.2021).

9. Стратегія національної безпеки України, затв. Указом Президента України від 14 вересня 2020 р. № 392/2020. URL: https://cutt.ly/6mJDTI3 (дата звернення: 01.08.2021).

10. Костенко О.М. Корупція в Україні у світлі політичної кримінології. Політичний менеджмент. 2009. № 1. С. 49-54.

11. Кваша О.О., Костенко О.М. Протидія корупції має ґрунтуватися на науковому підході: думки експертів. Правова держава. 2017. Вип. 28. С. 577-582.

12. Михайлов М.В. Національна безпека України як об'єкт посягання при корупційному підкупі. Південноукраїнський правничий часопис. 2020. № 4. С. 91-96.

13. Мельник М.I. Корупція - корозія влади (соціальна сутність, тенденції та наслідки, заходи протидії) : монографія. Київ : Юридична думка, 2004. 400 с.

14. Конвенція ОOH проти корупції від 31 жовтня 2003 p. URL: https://cutt.ly/RQdJ4yd (дата звернення: 01.08.2021).

15. Скакун О.Ф. Теория государства и права : энциклопедический курс : учебник. Харьков : Эспада, 2007. 840 с.

16. Бородін Ю.Ю. Поняття, ознаки та властивості правопорядку. Вісник Львівського державного університету. 2012. № 2(1). С. 211-221.

17. Рабінович П.М. Основи загальної теорії права та держави : навчальне видання. 2 вид., зі зм. й доп. Київ, 1994. 236 с.

18. Туляков В.О. Сингулярність кримінального права та державний примус. Правовий вплив на неправомірну поведінку: актуальні грані : монографія. Миколаїв : Іліон, 2016. С. 23-30.

19. Пов'язувати. Словник української мови (1970-1980) : в 11-и т. URL: https://cutt.ly/2QdKwR0 (дата звернення: 01.08.2021). 